\title{
THE POTENTIAL OF COCONUT SHELL POWDER (CSP) AND COCONUT SHELL ACTIVATED CARBON (CSAC) COMPOSITES AS ELECTROMAGNETIC INTERFERENCE (EMI) ABSORBING MATERIAL
}

\author{
(Potensi Serbuk Tempurung Kelapa (CSP) dan Karbon Teraktif Tempurung Kelapa (CSAC) \\ Sebagai Bahan Penyerap Gangguan Elektromagnatik)
}

\author{
Siti Nurbazilah Ab. Jabal ${ }^{1}$, Yew Been Seok ${ }^{1}$, Wee Fwen Hoon ${ }^{2}$ \\ ${ }^{\text {I}}$ Faculty of Innovative Design and Technology, \\ Universiti Sultan Zainal Abidin, Kampus Gong Badak, 21300 Kuala Terengganu, Terengganu, Malaysia \\ ${ }^{2}$ Embedded Computing Research Cluster, School of Computer and Communication Engineering, \\ Universiti Malaysia Perlis, Jalan Kangar-Alor Star, Taman Pertiwi Indah Seriab, 01000 Kangar, Perlis, Malaysia
}

*Corresponding author: bseokyew@unisza.edu.my

Received: 14 April 2015; Accepted: 30 November 2015

\begin{abstract}
Agriculture waste is potentially useful as an alternative material to absorb and attenuate electromagnetic interference (EMI). This research highlights the use of coconut shell powder (CSP) and coconut shell activated carbon (CSAC) as raw materials with epoxy resin and amine hardener composite to absorb microwave signals over frequency of $1-8 \mathrm{GHz}$. In order to investigate the suitability of these raw materials as EMI absorbing material, carbon composition of the raw materials is determined through CHNS Elemental Analysis. The surface morphology of the raw materials in term of porosity is investigated by using TM3000 Scanning Electron Microscope (SEM). The complex permittivity of the composites is determined by using high temperature dielectric probe in conjunction with Network Analyzer. From the result, the Carbon\% of CSP and CSAC is $46.70 \%$ and $84.28 \%$ respectively. In term of surface morphology, the surface porosity of CSP and CSAC is in the range of $2 \mu \mathrm{m}$ and $1 \mu \mathrm{m}$ respectively. For the dielectric properties, the dielectric constant and the dielectric loss factor for CSP and CSAC is 4.5767 and 64.8307and 1.2144 and 13.8296 respectively. The materials more potentially useful as substitute materials for electromagnetic interference (EMI) absorbing are discussed.
\end{abstract}

Keywords: agricultural wastes, dielectric properties, carbon composition

\begin{abstract}
Abstrak
Sisa pertanian mempunyai potensi untuk digunakan sebagai bahan alternatif untuk menyerap atau melemahkan gangguan elektromagnatik (EMI). Kajian ini menekankan kepada penggunaan serbuk tempurung kelapa (CSP) dan karbon teraktif tempurung kelapa(CSAC) sebagai bahan mentah dengan campuran resin epoksi dan komposit penguat amina untuk menyerap gelombang mikro dalam frekuensi $1-8 \mathrm{GHz}$. Bagi mengkaji kesesuaian bahan mentah sebagai bahan penyerap gelombang mikro, komposisi karbon dalam bahan mentah ditentukan mengunakan analisis unser CHNS. Liang permukaan bahan mentah pula dikaji mengunakan mikroskop pengimbas elektron TM3000 (SEM). Ketelusan kompleks bagi bahan campuran diukur menggunakan prob dielektrik suhu tinggi dan alat analisis rangkaian. Daripada keputusan yang diperolehi, peratusan karbon dalam CSP dan CSAC adalah sebanyak $46.70 \%$ dan $84.28 \%$. Manakala dari segi liang permukaan pula, keliangan CSP dan CSAC masing - masing berada dalam lingkungan 2um dan 1um.Bagi sifat dielektrik, pemalar dielektrik untuk CSP dan CSAC masing - masing adalah 4.5767 dan 64.8307. Bagi pembelauan dielektrik, nilai untuk CSP dan CSAC masing - masing adalah 1.2144 dan 13.8296. Isu bahan yang lebih berpotensi untuk digunakan sebagai bahan penyerap gangguan elektromagnatik (EMI) dibincangkan.
\end{abstract}




\section{Siti Nurbazilah et al: THE POTENTIAL OF COCONUT SHELL POWDER (CSP) AND COCONUT SHELL ACTIVATED CARBON (CSAC) COMPOSITES AS ELECTROMAGNETIC INTERFERENCE (EMI) ABSORBING MATERIAL}

Kata kunci: sisa pertanian, sifat dielektrik, komposisi karbon

\section{Introduction}

Recently, researchers have focused to identify the agricultural wastes (organic materials) as a new absorbing material. Agricultural waste is made up of organic compounds from living plant like oil palm shell, rice husk, and coconut shell. Many natural substances (agricultural wastes) are used as base materials to make activated carbon. The most common being used in absorbing material are sugarcane, rice husk, ground nut shell, oil palm shell, coconut shell, corncobs, durian shell, soybean oil cake [1-6]. At present, coconut wastes are used in horticultural and agricultural applications [7]. Carbon is the main element to absorb unwanted electromagnetic signals [8-12].

The French chemist Antoine-Alexandre-Brutus Bussy who in a 1822 is the first publication suggested that porosity was important to the adsorptive properties of activated carbons. Optical microscopy and scanning electron microscopy (SEM) have demonstrated enormous potential for use in the study and characterization of activated carbons because of their ability to directly view the micro-structure of activated carbons $[13,14]$

Dielectric properties are the main characteristic that determines a material to absorb energy. The dielectric properties $(\varepsilon)$ are derived from transmission line theory [15-17] and are expressed as complex permittivity, shown in Equation 1:

$$
\varepsilon=\varepsilon^{\prime}-j \varepsilon^{\prime \prime}
$$

where $\varepsilon$ is define as dieletric properties, $\varepsilon$ ' is define dieletric constant and $\varepsilon$ "' define as dieletric loss factor.

Dielectric constant $(\varepsilon)$ is the real part of the complex permittivity whereas the imaginary part of the complex permittivity is called the dielectric loss factor $(\varepsilon ")$. The dielectric constant and dielectric loss factor effect the ability of a material to act as microwave absorber. The dielectric constant defines the ability of a material to store the microwave energy while the dielectric loss factor defines the ability of a material to convert and dissipate the stored microwave energy to heat. In other words, microwave absorber prefers materials that possess higher thermal conductivity because when the thermal conductivity increases, the ability of these materials to dissipate heat also increase.

In this paper, the potential of CSP and CSAC with epoxy resin and amine hardener composite will be investigated.

\section{Material preparation}

\section{Materials and Methods}

For the coconut shell source, it was economically important to use a readily available agricultural waste by product. To manufacture coconut shell powder, the shells of fully matured nuts are first cleaned of the adhering pithy matter. The matured coconut shells were taken from Kuala Ibai, Terengganu, Malaysia. The coconut shell is sanded using sanding machine in order to get the coconut shell powder. The readymade CSAC powder was bought from Tan Meng Keong Sdn. Bhd company, Perak Darul Ridzuan, Malaysia.

\section{Material characterisation}

The carbon composition of the CSP and CSAC is determined by using ultimate analyses through CHNS Elemental Analysis. The CHNS elemental analysers provide a means for rapid determination of carbon, hydrogen, nitrogen and sulphur in organic matrices $[18,19]$. In order to investigate the surface morphology of CSP and SCAC materials in term of porosity, sample was investigated by using TM3000 Scanning Electron Microscope. For SEM measurements, the samples were prepared by coated with a thin layer of platinum [5-20].

\section{Composite preparation}

The raw material was mix with epoxy resin matrix and the composites were prepared in weight ratio 80: 20 (80\% for raw material, $20 \%$ of epoxy resin). Sample 1, the CSP composites were stirred by using IKA RW20 Digital Stare for 1 hour. Sample 2 was prepared in similar manner but using CSAC. The mixture was poured in $30 \mathrm{~mm} \mathrm{x}$ 
$30 \mathrm{~mm} \times 5 \mathrm{~mm}$ rectangular planner moulds. Fabrication of sample 1 can be done through the steps summarized in Figure 1 below.

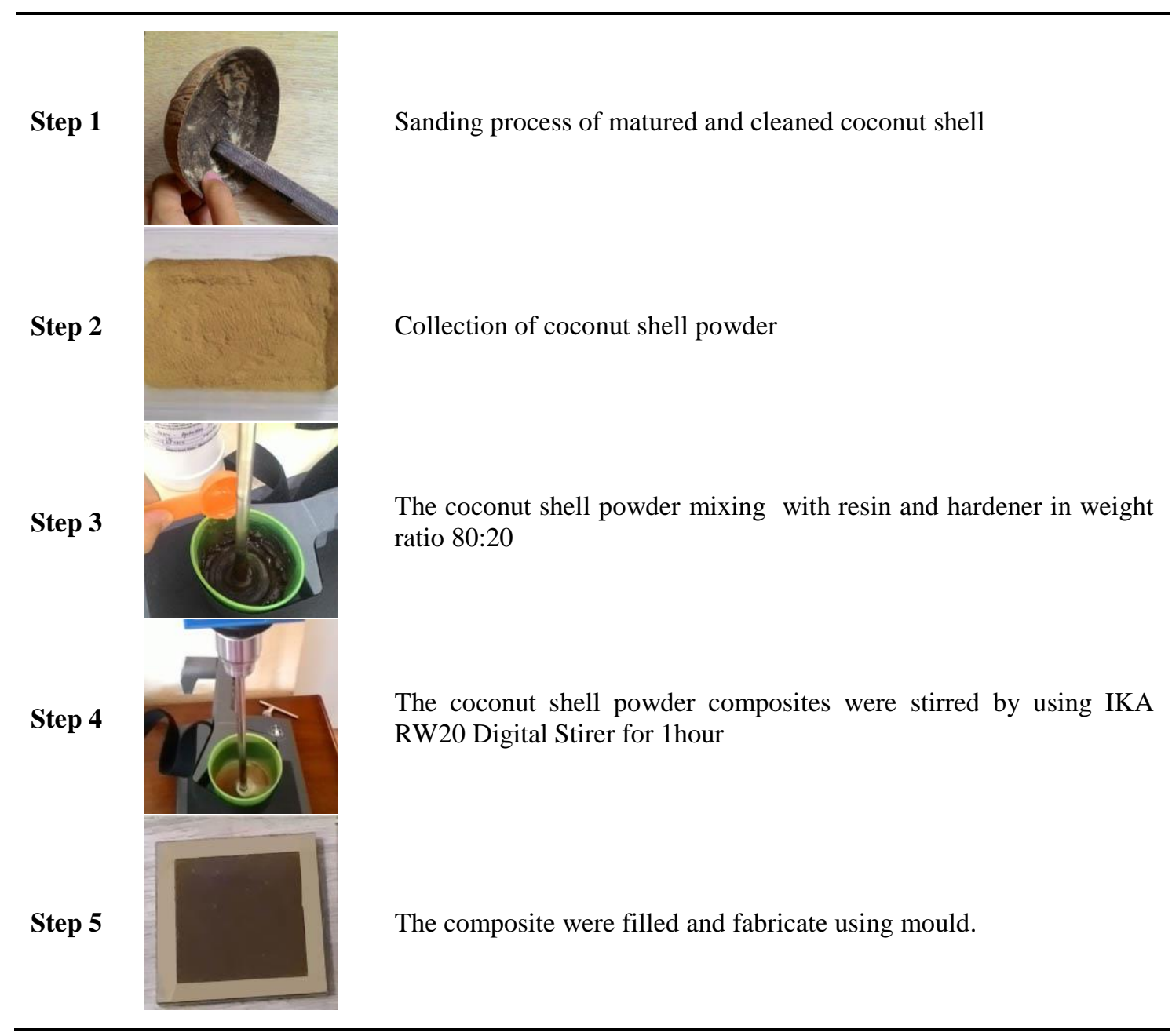

Figure 1. Fabrication of composite sample

\section{Dielectric Properties Measurement}

Several popular measurement techniques are the transmission line techniques (waveguide, coaxial and free-space), impedance, dielectric probe and cavity methods [21]. Amongst these techniques, high temperature dielectric probe techniques are chosen to determine of the complex permittivity of the coconut shell powder and coconut shell activated carbon polymer composite dielectric properties measurement. The high temperature dielectric probe is performed by contacting the probe into the samples. The high temperature probe measurement procedure, which is done by contacting the probe to a flat surface of a sample, is shown in Figure 2. The fields at the probe end "fringe" into the material and change as they come into contact with the MUT. 
Siti Nurbazilah et al: THE POTENTIAL OF COCONUT SHELL POWDER (CSP) AND COCONUT SHELL ACTIVATED CARBON (CSAC) COMPOSITES AS ELECTROMAGNETIC INTERFERENCE (EMI) ABSORBING MATERIAL

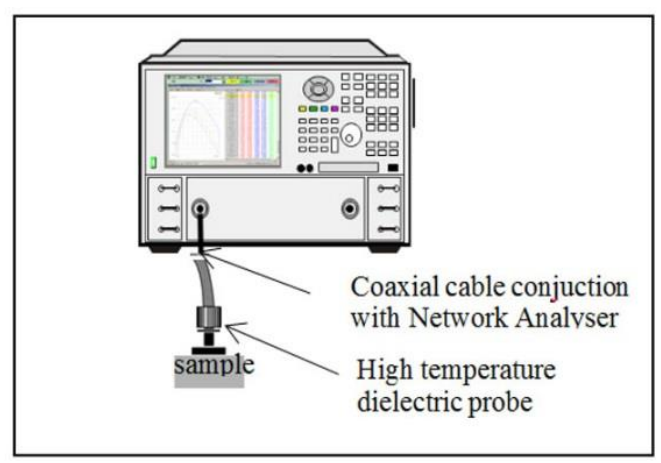

Figure 2. Measurement techniques for CSP and CSAC composites: High Temperature Dielectric Probe Technique

\section{Carbon composition}

\section{Results and Discussion}

The carbon composition of the CSP and CSAC is determined through CHNS Elemental Analysis. The CHNS Elemental Analysis determines the percentages of Carbon, Hydrogen, Nitrogen and Sulphur [22]. The result of elemental analysis of CSP and CSAC is presented in Table 1.

Table 1. The CHNS Elemental Analysis of CSP and CSAC

\begin{tabular}{lcccccccccc}
\hline \multirow{2}{*}{ Material } & \multirow{2}{*}{$\begin{array}{c}\text { Total } \\
\text { Mass }\end{array}$} & \multicolumn{2}{c}{ Carbon } & \multicolumn{2}{c}{ Hydrogen } & \multicolumn{2}{c}{ Nitrogen } & \multicolumn{2}{c}{ Sulphur } & \multirow{2}{*}{ Oxygen } \\
\cline { 3 - 12 } & $(\mathbf{m g})$ & $\mathbf{\%}$ & $\mathbf{m g}$ & $\mathbf{\%}$ & $\mathbf{m g}$ & $\mathbf{\%}$ & $\mathbf{m g}$ & $\mathbf{\%}$ & $\mathbf{~ m g}$ & (by diff) \\
\hline CSP & 2.0120 & 46.70 & 0.94 & 3.174 & 0.064 & 0.171 & 0.003 & 1.036 & 0.021 & 48.92 \\
CSAC & 2.0140 & 84.28 & 1.697 & 0.478 & 0.010 & 0.222 & 0.005 & 1.084 & 0.022 & 13.94 \\
\hline
\end{tabular}

As presented in Table 1, the carbon \% of CSP and CSAC is $46.70 \%$ and $84.28 \%$ respectively. The CSP has lower carbon content compare to CSAC. The high composition of carbon in the coconut shell as presented from the elemental analysis indicates a good precursor material for porous carbon [23].

CSAC have higher carbon content compared to CSP because to produce activated carbon from coconut shells, the overall process utilizes the pyrolysis of coconut shells into char, followed by steam activation in a fluidized bed reactor (FBR). The resulting activated carbon is $97 \%$ pure.

\section{Surface Morphology}

SEM morphologies in Figure 3 and Figure 4 shown reveal details of activated porosity development of CSP and CSAC.

The most important property of the activated carbon is its adsorptive capacity, which in general is proportional to the surface area $[24,25]$. Carbon's highly porous nature provides a large surface area for absorption. The application of activated carbon in absorption processes mainly depends on the surface chemistry and pore structure of porous carbon [26]. While, Li et al. said that activated carbon having porous structure and high surface area where the pore structure is importance for optimal performance for absorbing material [27]. CSAC is an excellent quality high surface area material [28]. 


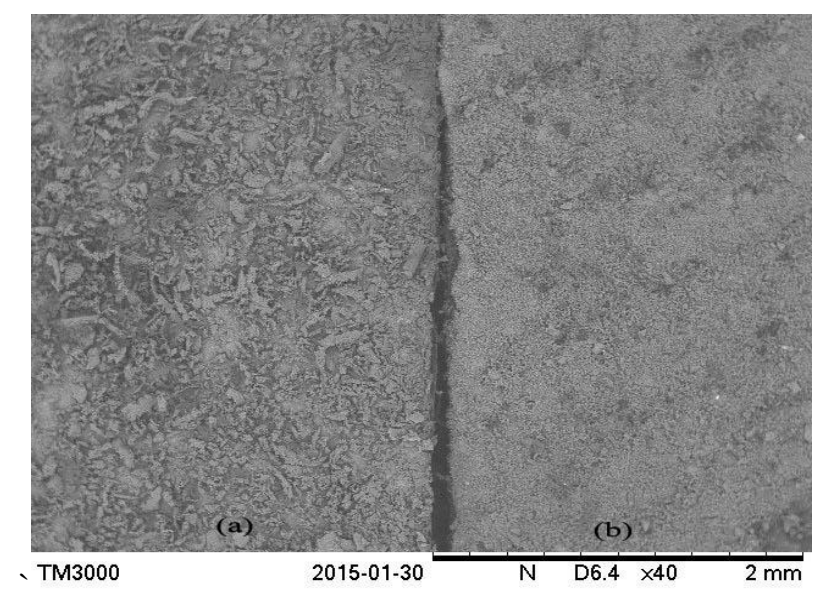

Figure 3. SEM morphology on composite surface (a) CSP; (b) CSAC

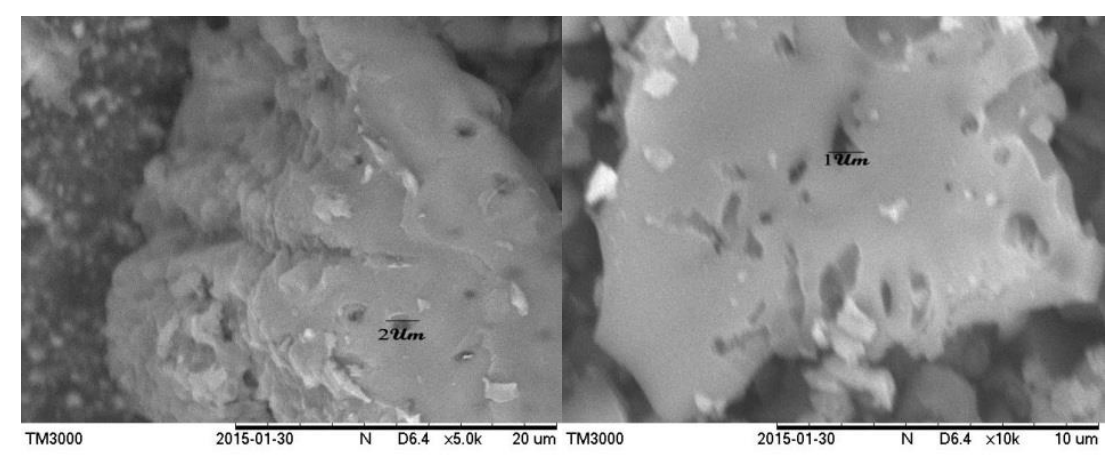

(a)

(b)

Figure 4. SEM morphology on particle porosity (a) CSP; (b) CSAC

In Figure 4, presence of mesopores is detected in CSP and CSAC where the porosity is in the range of 2um and 1um respectively.

\section{Dielectric Properties}

The result of dielectric properties of CSP and CSAC over frequency of 1-8 GHz is presented in Table 2.

Figure 5 (a) and (b) show the dielectric properties that were measured from CSP and CSAC composites. The dielectric constant and dielectric loss factor vary when the frequency increased from $1 \mathrm{GHz}$ to $8 \mathrm{GHz}$. It can be observed that the dielectric properties of the CSAC composite are higher compared to the CSP composite. This is due to the high carbon composition in the CSAC compared to the raw CSP. 
Siti Nurbazilah et al: THE POTENTIAL OF COCONUT SHELL POWDER (CSP) AND COCONUT SHELL ACTIVATED CARBON (CSAC) COMPOSITES AS ELECTROMAGNETIC INTERFERENCE (EMI) ABSORBING MATERIAL

Table 2. Dielectric properties for CSP and CSAC

\begin{tabular}{llccc}
\hline \multirow{2}{*}{$\begin{array}{l}\text { Frequency } \\
(\mathbf{G H z})\end{array}$} & $\begin{array}{l}\text { Sample } \\
\text { Composite }\end{array}$ & $\begin{array}{c}\text { Dielectric Constant } \\
(\boldsymbol{\varepsilon})\end{array}$ & $\begin{array}{c}\text { Dielectric Properties } \\
\text { Dielectric Loss Factor } \\
\left(\boldsymbol{\varepsilon}^{\prime}\right)\end{array}$ & $\begin{array}{c}\text { Loss Tangent } \\
(\tan \delta)\end{array}$ \\
\hline \multirow{2}{*}{1} & CSP & 5.1244 & 0.5200 & 0.1015 \\
& CSAC & 64.8307 & 18.0791 & 0.2789 \\
2 & CSP & 5.0726 & 0.7029 & 0.1386 \\
& CSAC & 60.8409 & 14.7596 & 0.2426 \\
3 & CSP & 4.8108 & 0.7497 & 0.1558 \\
& CSAC & 58.6587 & 13.6022 & 0.2319 \\
4 & CSP & 4.8539 & 0.8508 & 0.1753 \\
& CSAC & 57.5637 & 13.6078 & 0.2364 \\
5 & CSP & 4.6504 & 0.9517 & 0.2046 \\
& CSAC & 56.1002 & 13.7901 & 0.2459 \\
6 & CSP & 4.5765 & 1.0525 & 0.2300 \\
& CSAC & 54.9361 & 13.7144 & 0.2497 \\
7 & CSP & 4.4164 & 1.1331 & 0.2566 \\
& CSAC & 54.2399 & 14.0169 & 0.2584 \\
8 & CSP & 3.1100 & 1.2144 & 0.3905 \\
& CSAC & 52.0081 & 13.8296 & 0.2659 \\
\hline
\end{tabular}
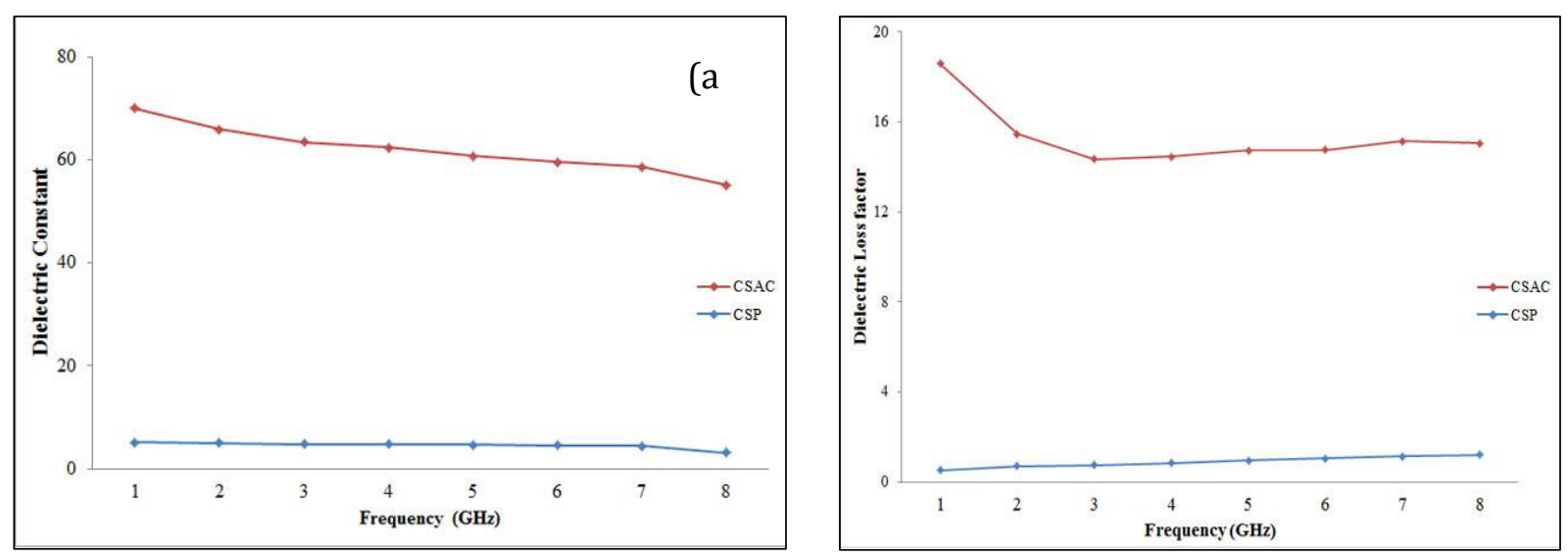

Figure 5. (a) Dielectric constant of CSP and CSAC; (b) Dielectric loss factor of CSP and CSAC

\section{Conclusion}

From this experiment, we investigate the potential of CSP and CSAC composites as EMI absorbing material in term of carbon composition, surface morphology and dielectric properties. Both CSP and CSAC composites show desirable potential to be used as EMI absorbing material, in term of carbon as dominant element, mesopores porosity and thermal conductivity. From the result, CSAC composite possess better carbon composition, surface morphology and thermal conductivity compared to CSP composite. 


\section{Acknowledgement}

The authors would like to thank to UniSZA for supporting this research and MOHE for providing research grant (RAGS/1/2014/TK06/UNISZA//1), UniMAP for providing the facilities for measurement purpose, by means of Agilent E8362B P-series Network Analyser and TM3000 Scanning Electron Microscope and Universiti Malaya for providing the CHNS Elemental Analyser for measurement purpose.

\section{References}

1. Salleh M. K. M., Yahya M., Awang Z., Muhamad W. N. W., Mozi A.M. and Yaacob N. (2011). Single layer coconut shell - based microwave absorber. IEEE TENCON: pp 1110 - 1113.

2. Sivakumar, K. and Mohan, N. K. (2010). Performance analysis of downdraft gasifier for agriwaste biomass materials. Indian Journal of Science and Technology, 3: 58 - 60.

3. Daud, W. M. A. W. and Ali, W. S. W. (2004). Comparison on pore development of activated carbon produced from palm shell and coconut shell. Bioresource Technology, 93: 63-69.

4. Cobb, A., Warms, M., Maurer, E. P. and Chiesa, S. (2012). Low-tech coconut shell activated charcoal production. International Journal for Service Learning in Engineering, 7: 93 -104.

5. Chandra, T. C., Mirna, M. M., Sunarso, J., Sudaryanto, Y. and Ismadji, S. (2009). Activated carbon from durian shell: preparation and characterization. Journal of Taiwan Institute Chemical Engineering. 40: 457 - 462.

6. Tay, T., Ucar, S. and Karagoz, S. (2009). Preparation and characterization of activated carbon from waste biomass. Journal of Hazardous Materials, 165: 481 - 485.

7. Cresswell, G., (2011). Coir dust a proven alternative to peat. Cresswell Horticulrutal Services (Report): 1 - 13.

8. Yusof, A. A. (2004). Thesis The development of microwave absorber from oil palm shell carbon.

9. Yusof, A. A., Ali, W. K. W., Rahman, T. A. and Ani F. N. (2005). Microwave and reflection properties of palm shell carbon-polyester conductive composite absorber. Jurnal Teknologi, 42: 59 - 74.

10. Zahid, L., Malek, M. F. B. A., Nornikman, H., Mohd Affendi, N. A., Ali, A., Hussin, N., Ahmad B. H. and Abdul Aziz, M. Z. A. (2013). Development of pyramidal microwave absorber using sugar cane bagasse (SCB). Progress in Electromagnetics Research, 137: 687 - 702.

11. Menéndez, J. A., Arenillas, A., Fidalgo, B., Fernández, Y., Zubizarreta, L., Calvo, E. G. and Bermúdez, J. M. (2010). Microwave heating processes involving carbon materials. Fuel Processing Technology, 91: $1-8$.

12. Information from Biofuels Research Infrastructure for Sharing Knowledge (BRISK), Database for biomass and waste, Retrived from https://www.ecn.nl/phyllis2/

13. Achaw, O-W. and Afrane, G. (2008). The evolution of pore structure of coconut shells during the preparation of cocnut shell-based activated carbons. Microporous and Mesoporous Materials, 112: 284 - 290.

14. Mfanacho, S. M., Hemang, P. and Manocha, L. M. (2010). Enhancement of microporosity through physical activation. PRAJ $\tilde{N} \bar{A}$ - Journal of Pure and Applied Sciences, 18: 106 - 109.

15. Saini, P., Arora, M. and Ailton, D.S.G. (2012). Microwave absorption and EMI shielding behaviour of nanocomposites based on intrinsically conducting polymers, graphene and carbon nanotubes. In Chapter 3 . Crotia: InTech Publishing: pp $1-42$.

16. Li, S., Chen, S., Anwar, S., Lu, W., Lai, Y., Chen, H., Hou, B., Ren, B, F. and Gu, B. (2012). Applying Effective Medium Theory in Characterizing Dielectric Constant of Solids. Progress in Electromagnetics Research. 35: $145-153$.

17. Micheli, D., Apollo, C., Pastore, R., Morles, R.B., Marchetti, M., Gradoni, G. edited by Reddy, B. (2011). Electromagnetic characterization of composite materials and microwave absorbing modelling in Chapter 16. InTech Publishing: pp $359-384$.

18. Thompson, M. (2008). CHNS Elemental Analysers (Analytical Methods Committee). Royal Chemical Society: pp $1-2$.

19. Meena, P. L., Saxena, R. and Sharma, N. (2014). A rapid analytical method using flow injection preconcentration of zinc on dithizone impregnated on amberlite XAD-2 and its determination in water samples by FAAS. International Journal of Agriculture and Food Science Technology, 5: 287 - 296.

20. Koboski, K. R., Nelsen, E. F. and Hampton, J. R. (2013). Hydrogen evolution reaction measurements of dealloyed porous $\mathrm{NiCu}$. Nanoscale Research Letters, 8: 528 - 535.

21. Hoon, W. F., Jack, S. P., Malek, M. F. A. and Hasssan, N. (2012). Alternatives for pcb laminates: dielectric properties' measurements at microwave frequencies in Chapeter 5. InTech Publishing. 
Siti Nurbazilah et al: THE POTENTIAL OF COCONUT SHELL POWDER (CSP) AND COCONUT SHELL

\section{ACTIVATED CARBON (CSAC) COMPOSITES AS ELECTROMAGNETIC}

INTERFERENCE (EMI) ABSORBING MATERIAL

22. Chakma, S., Vaishya, R. C. and Yadav, A. K. (2015). Modeling chemical compositions of municipal solid waste. Environmental Geotechnics (Article in Press): September 11, 2015

23. Cazetta, A. L., Vargas, A. M. M., Nogami, E. M., Kunita, M. H., Guiherme, M. R., Martins, A. C., Silva, T. L., Moraes, J. C. G. and Almeid, V. C. (2011). NaOH activated carbon of high surface area produced from coconut shell: kinetics and equilibrium studies from the methylene blue adsorption. Chemical Engineering Journal, 174: $117-125$.

24. Demiral, H., Demiral, I., Karabacakoglu, B. and Tumsek. F. (2011). Production of activated carbon from olive bagasse by physical activation. Chemical Engineering Research and Design, 89: 206 - 213.

25. Nasria, N. S., Jibrila, M., Zaini, M .A. A., Mohsin, R. Daduma, H. U. and Musa, A. M. (2014). Synthesis and characterization of green porous carbons with large surface area by two step chemical activation with $\mathrm{KOH}$. Jurnal Teknologi. 67(4): 25 - 28.

26. Bhatnagar, A., Hogland, W., Marques, M. and Sillanpaa, M. (2013). An overview of the modification methods of activated carbon for its water treatment applications. Chemical Engineering Journal, 219: 499-511.

27. Iqbaldin, M. M., Khudzir, I., Azlan, M. M., Zaidi, A. G., Surani, B. and Zubri, Z. (2013). Properties of coconut shell activated carbon. Journal of Tropical Forest Science, 25: 497 - 503.

28. Atwater, J. E. and Jr. R.R. Wheeler. (2004). Microwave permittivity and dielectric relaxation of a high surface area activated carbon. IEEE Electrical Insulation Magazine, 17(2): 66 - 66. 